\title{
Methodology for Assessment of Undiscovered Oil and Gas Resources for the 2008 Circum-Arctic Resource Appraisal
}

Chapter B of

The 2008 Circum-Arctic Resource Appraisal

Professional Paper 1824

U.S. Department of the Interior

U.S. Geological Survey 
View to the east of the Lisburne well during active drilling in July 1979, Ivotuk Hills, northern Alaska. U.S. Geological Survey photo by Thomas Moore. 


\section{Methodology for Assessment of Undiscovered Oil and Gas Resources for the 2008 Circum-Arctic Resource Appraisal}

By Ronald R. Charpentier

Chapter B of

The 2008 Circum-Arctic Resource Appraisal

Edited by T.E. Moore and D.L. Gautier

Professional Paper 1824 


\title{
U.S. Department of the Interior RYAN K. ZINKE, Secretary
}

\section{U.S. Geological Survey William H. Werkheiser, Acting Director}

\author{
U.S. Geological Survey, Reston, Virginia: 2017
}

For more information on the USGS — the Federal source for science about the Earth, its natural and living resources, natural hazards, and the environment-visit https://www.usgs.gov or call 1-888-ASK-USGS.

For an overview of USGS information products, including maps, imagery, and publications, visit https://store.usgs.gov.

Any use of trade, firm, or product names is for descriptive purposes only and does not imply endorsement by the U.S. Government.

Although this information product, for the most part, is in the public domain, it also may contain copyrighted materials as noted in the text. Permission to reproduce copyrighted items must be secured from the copyright owner.

Suggested citation:

Charpentier, R.R., 2017, Methodology for assessment of undiscovered oil and gas resources for the 2008 CircumArctic Resource Appraisal, chap. B of Moore, T.L., and Gautier, D.L., eds., The 2008 Circum-Arctic Resource Appraisal: U.S. Geological Survey Professional Paper 1824, 7 p., https://doi.org/10.3133/pp1824B

ISSN 2330-7102 (online) 


\section{The 2008 Circum-Arctic Resource Appraisal}

\section{Chapters}

A. Introduction to the 2008 Circum-Arctic Resource Appraisal (CARA) Professional Paper By Donald L. Gautier and Thomas E. Moore

B. Methodology for Assessment of Undiscovered Oil and Gas Resources for the 2008 Circum-Arctic Resource Appraisal

By Ronald R. Charpentier

\section{North America}

C. Geology and Assessment of Undiscovered Oil and Gas Resources of the Chukchi Borderland Province, 2008

By Kenneth J. Bird and David W. Houseknecht

D. Geology and Assessment of Undiscovered Oil and Gas Resources of the Hope Basin

Province, 2008

By Kenneth J. Bird, David W. Houseknecht, and Janet K. Pitman

E. Geology and Assessment of Undiscovered Oil and Gas Resources of the Arctic Alaska Petroleum Province, 2008

By David W. Houseknecht, Kenneth J. Bird, and Christopher P. Garrity

F. Geology and Assessment of Undiscovered Oil and Gas Resources of the Yukon Flats Basin Province, 2008

By Kenneth J. Bird and Richard G. Stanley

G. Geology and Assessment of Undiscovered Oil and Gas Resources of the Northwest Canada Interior Basins Province, Arctic Canada, 2008

By Marilyn E. Tennyson and Janet K. Pitman

H. Geology and Assessment of Undiscovered Oil and Gas Resources of the Franklinian Shelf Province, Arctic Canada and North Greenland, 2008

By Marilyn E. Tennyson and Janet K. Pitman

I. Geology and Assessment of Undiscovered Oil and Gas Resources of the Sverdrup Basin Province, Arctic Canada, 2008

By Marilyn E. Tennyson and Janet K. Pitman

\section{Greenland}

J. Geology and Assessment of Undiscovered Oil and Gas Resources of the West GreenlandEast Canada Province, 2008

By Christopher J. Schenk 
K. Geology and Assessment of Undiscovered Oil and Gas Resources of the East Greenland Rift Basins Province, 2008

By Donald L. Gautier

\section{North Atlantic Ocean}

L. Geology and Assessment of Undiscovered Oil and Gas Resources of the Jan Mayen Microcontinent Province, 2008

By Thomas E. Moore and Janet K. Pitman

\section{Eurasia}

M. Geology and Assessment of Undiscovered Oil and Gas Resources of the Mezen' Basin Province, 2008

By Timothy R. Klett and Janet K. Pitman

N. Geology and Assessment of Undiscovered Oil and Gas Resources of the Timan-Pechora Basin Province, Russia, 2008

By Christopher J. Schenk

0. Geology and Assessment of Undiscovered Oil and Gas Resources of the East Barents Basins Province and the Novaya Zemlya Basins and Admiralty Arch Province

By Timothy R. Klett

P. Geology and Assessment of Undiscovered Oil and Gas Resources of the North Kara Basins and Platforms Province, 2008

By Timothy R. Klett and Janet K. Pitman

0. Geology and Assessment of Undiscovered Oil and Gas Resources of the Northern West Siberian Mesozoic Composite Total Petroleum System of the West Siberian Basin Province, Russia, 2008

By Christopher J. Schenk

R. Geology and Assessment of Undiscovered Oil and Gas Resources of the Yenisey-Khatanga Basin Province, 2008

By Timothy R. Klett and Janet K. Pitman

S. Geology and Assessment of Undiscovered Oil and Gas Resources of the Northwest Laptev Sea Shelf Province, 2008

By Timothy R. Klett and Janet K. Pitman

T. Geology and Assessment of Undiscovered Oil and Gas Resources of the Lena-Anabar Basin Province, 2008

By Timothy R. Klett and Janet K. Pitman 
U. Geology and Assessment of Undiscovered Oil and Gas Resources of the Tunguska Basin Province, 2008

By Christopher J. Wandrey and Timothy R. Klett

V. Geology and Assessment of Undiscovered Oil and Gas Resources of the Lena-Vilyui Basin Province, 2008

By Timothy R. Klett and Janet K. Pitman

W. Geology and Assessment of Undiscovered Oil and Gas Resources of the Laptev Sea Shelf Province, 2008

By Timothy R. Klett and Janet K. Pitman

X. Geology and Assessment of Undiscovered Oil and Gas Resources of the Zyryanka Basin Province, 2008

By Timothy R. Klett and Janet K. Pitman

Y. Geology and Assessment of Undiscovered Oil and Gas Resources of the East Siberian Sea Basin Province, 2008

By Kenneth J. Bird, David W. Houseknecht, and Janet K. Pitman

Z. Geology and Assessment of Undiscovered Oil and Gas Resources of the Vilkitskii Basin Province, 2008

By Kenneth J. Bird, David W. Houseknecht, and Janet K. Pitman

AA. Geology and Assessment of Undiscovered Oil and Gas Resources of the Long Strait Province, Russian High Arctic, 2008

By Kenneth J. Bird, David W. Houseknecht, and Janet K. Pitman

\section{Arctic Ocean}

BB. Geology and Assessment of Undiscovered Oil and Gas Resources of the Amerasia Basin Petroleum Province, 2008

By David W. Houseknecht, Kenneth J. Bird, and Christopher P. Garrity

CC. Geology and Assessment of Undiscovered Oil and Gas Resources of the LomonosovMakarov Province, Central Arctic Ocean, 2008

By Thomas E. Moore, Kenneth J. Bird, and Janet K. Pitman

DD. Geology and Assessment of Undiscovered Oil and Gas Resources of the Eurasia Basin Province, Eastern Arctic Ocean, 2008

By Thomas E. Moore and Janet K. Pitman 


\section{Contents}

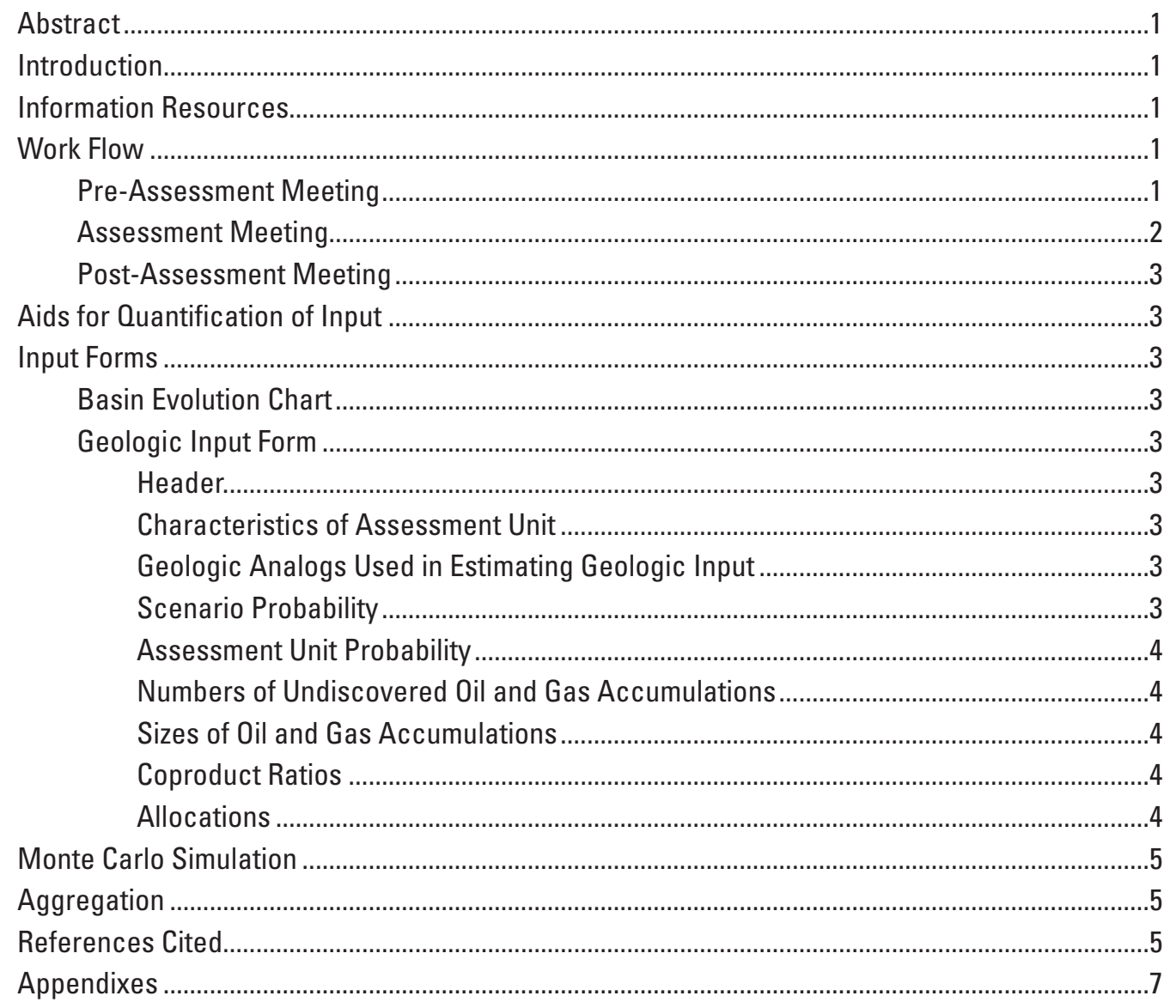

\section{Appendixes}

[Available for download at https://doi.org/10.3133/pp1824B]

1. Monte Carlo Program for Estimating Oil/Gas Accumation Mix

2. Basin Evolution Chart

3. Circum-Arctic Resource Appraisal Geologic Data Form for Conventional Assessment Units 


\section{Figures}

1. Diagram of work flow for the 2008 Circum-Arctic Resource Appraisal geologic assessments 2

\section{Table}

1. Global default values for coproduct ratios and ancillary data used in the Circum-Arctic Resource Appraisal geologic assessments ................................................................ 



\title{
Chapter B
}

\section{Methodology for Assessment of Undiscovered Oil and Gas Resources for the 2008 Circum-Arctic Resource Appraisal}

\author{
By Ronald R. Charpentier
}

\section{Abstract}

The methodological procedures used in the geologic assessments of the 2008 Circum-Arctic Resource Appraisal (CARA) were based largely on the methodology developed for the 2000 U.S. Geological Survey World Petroleum Assessment. The main variables were probability distributions for numbers and sizes of undiscovered accumulations with an associated risk of occurrence. The CARA methodology expanded on the previous methodology in providing additional tools and procedures more applicable to the many Arctic basins that have little or no exploration history. Most importantly, geologic analogs from a database constructed for this study were used in many of the assessments to constrain numbers and sizes of undiscovered oil and gas accumulations.

\section{Introduction}

This chapter outlines the methodology used in the 2008 Circum-Arctic Resource Appraisal (CARA), including the conceptual approach, information resources, reasoning, assumptions, procedures, statistical methods, and software employed to evaluate the undiscovered petroleum resources of the Arctic region. The 2008 CARA methodology used probability distributions for numbers and sizes of undiscovered accumulations paired with an associated risk of occurrence. These methods are similar to those developed for the 2000 World Petroleum Assessment (U.S. Geological Survey World Energy Assessment Team, 2000), but the CARA methodology used additional tools and procedures more appropriate to the many underexplored basins in the Arctic, particularly the use of analogs from a geologic analog database.

The methodology depended upon two principles. First, the assessors should be allowed as much flexibility in approach as possible to assess undiscovered oil and gas resources. Although many of the Arctic oil and gas assessments were in areas with little or no exploration, some provinces had discoveries and those data must be incorporated in the analysis. Second, the final output should be presented in terms of numbers and sizes of undiscovered oil and gas accumulations in order to facilitate comparisons among assessments.

\section{Information Resources}

The primary sources of information for the 2008 CARA were the literature as well as personal contacts and discussions with international organizations and individuals. Previous assessments by the USGS and the Minerals Management Service (MMS; now the Bureau of Ocean Energy Management and the Bureau of Safety and Environmental Enforcement, following reorganization in October 2011) for northern Alaska were available and were incorporated into the CARA assessments. A few specific sources of information require special comment here.

A map of the Arctic region by Grantz and others (2010) served as the basis for delineating geologic provinces, total petroleum systems, and assessment units. Information from this map was used to aid in developing basin evolution charts.

The major proprietary database used for CARA was the IHS Energy International Exploration and Production Database (IHS Energy, 2007). As many of the provinces did not have discovered fields, analogs were used frequently. A geologic analog database (Charpentier and others, 2008) was constructed based on the 246 assessment units quantitatively assessed for the 2000 USGS World Energy Assessment.

\section{Work Flow}

The work flow outlined below is for the analysis of a CARA geologic province. This work flow was preceded by the division of the Arctic into provinces and assignment of the responsibility for each province to an individual geoscientist or small group of geoscientists. A flow chart is shown in figure 1.

\section{Pre-Assessment Meeting}

The initial part of the study included data collection and interpretation, leading to a set of proposed total petroleum systems and geologic assessment units. As part of this process of data interpretation, geologic models were developed that formed the foundation upon which estimates were made of sizes and numbers of undiscovered oil and gas accumulations within each assessment unit. 


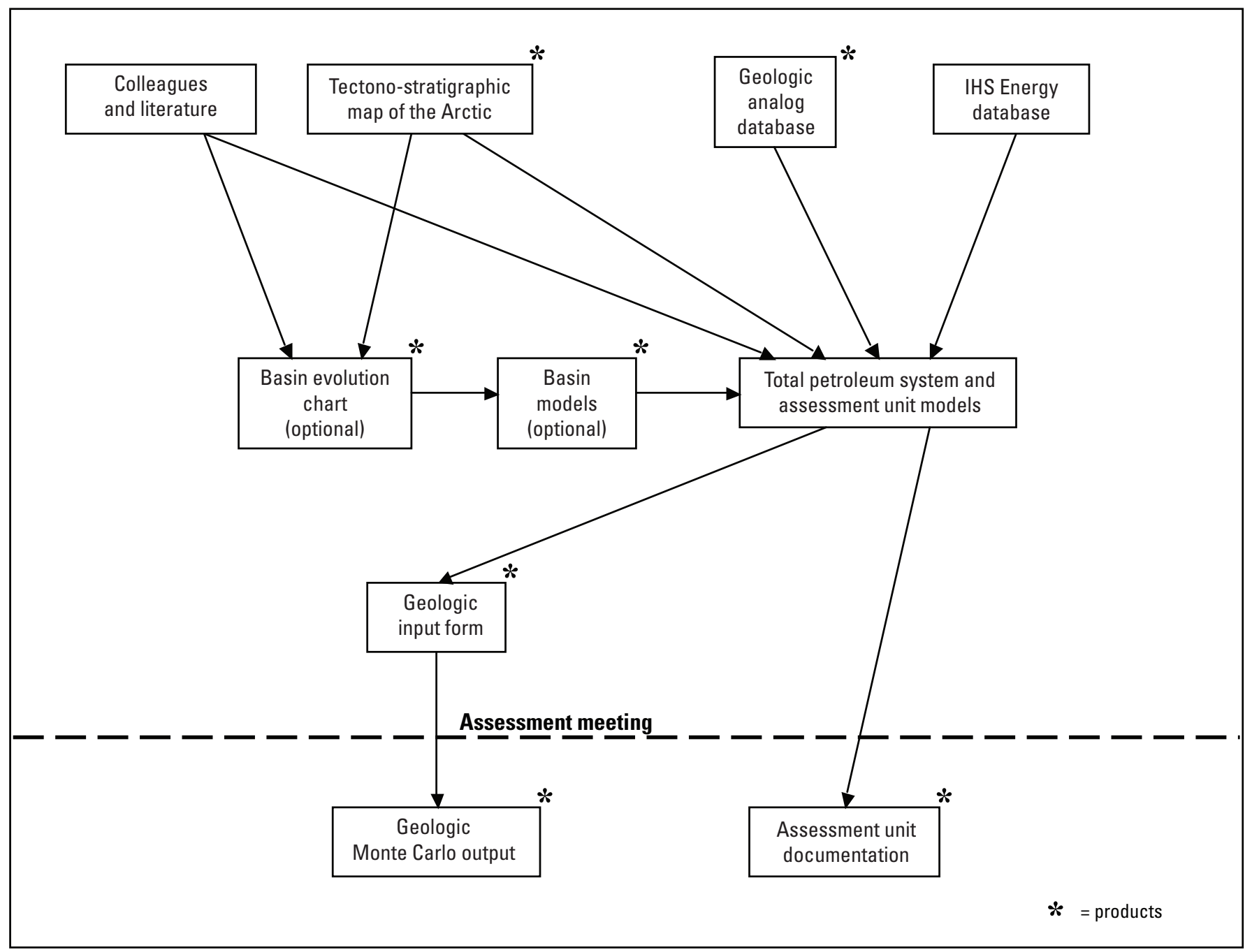

Figure 1. Diagram of work flow for the 2008 Circum-Arctic Resource Appraisal geologic assessments.

Following the definition of total petroleum systems and assessment units, discovered accumulations were allocated to assessment units. For those assessment units with discovered oil and gas accumulations, a spreadsheet of the relevant data and accompanying exploration history plots were prepared, and an exploration model was developed to explain the controls on exploration and its results. Areas were calculated as needed for the allocation of resources on the geologic input form.

Two optional products were generated during this phase. The basin evolution chart was completed, based on the available geologic information and the Grantz and others (2010) map. The basin evolution chart also provided a source of input for basin modeling, which was also completed prior to the assessment meeting.

The geologic input form for each assessment unit was completed by the assessor responsible for that province. The geologic analog database was used to select sets of appropriate analogs and to assist in generating distributions of numbers and sizes of undiscovered accumulations.

\section{Assessment Meeting}

The purpose of the assessment meeting was to evaluate the set of proposed total petroleum systems and assessment units using the broader experience of the assessment review committee. The geologic models and exploration models for each assessment unit were discussed, as they formed much of the basis of the assessment. The set of proposed total petroleum systems and assessment units was finalized. If necessary because of changes in assessment unit definitions, changes were made to the exploration history plots and the areas calculated for allocation.

At the assessment meeting, the input forms were evaluated and revised, again using the broader experience of the assessment review committee. The input was finalized and any modifications of geologic concepts were documented by the assessor. 


\section{Post-Assessment Meeting}

With input from the finalized geologic input form, the Monte Carlo simulation programs were run to 50,000 iterations for official results. After calculation of assessment unit results, aggregate results were calculated.

\section{Aids for Quantification of Input}

Two main aids for quantification of input were developed for CARA: a geologic analog database (Charpentier and others, 2008) and a program for probabilistically handling uncertainty in the mix of oil and gas accumulations (appendix 1).

A geologic analog database was created using the 246 assessment units quantitatively assessed in the 2000 USGS World Petroleum Assessment (Charpentier and others, 2008). Most of the variables required for the geologic input form were represented directly or indirectly in the geologic analog database. The documentation for the geologic analog database contained information on use, including examples and directions for using the search and graph tools.

Estimation of numbers and sizes of undiscovered accumulations might use several variables from the geologic analog database. The appropriate database variables were numbers of accumulations per $1,000 \mathrm{~km}^{2}$, median and maximum oil and gas accumulation sizes, and ratios of numbers of oil to gas accumulations. Coproducts and ancillary data were also taken from the geologic analog database.

The relative mix between oil and gas accumulations may be uncertain in frontier provinces. A Monte Carlo program was developed to address this problem (appendix 1).

\section{Input Forms}

\section{Basin Evolution Chart}

The basin evolution chart was developed for the CARA study as a method of summarizing much of the geologic history of a province in a standard format. The basin evolution chart is shown in appendix 2.

The left side of the chart provides a geologic time scale, against which basin history is plotted. Columns showing major global source-rock intervals, global temperatures, and sealevel curves are provided for reference. The section on basin evolution provides information needed for basin thermal-history modeling. The last section is similar to a standard petroleum system chart, documenting timing for source, reservoirs, seals, traps, and fluid generation and destruction.

\section{Geologic Input Form}

The geologic input form is shown in appendix 3. The input form is based on the Seventh Approximation Input Form, originally devised for the 2000 World Petroleum Assessment (U.S. Geological Survey World Energy Assessment Team, 2000) and used (with several revisions) in subsequent USGS assessments.

\section{Header}

The header identifies the assessment unit and places it within a hierarchy of region-province-total petroleum systemassessment unit. The code system for this hierarchy is consistent with that used in the 2000 World Petroleum Assessment. The original region numbers were maintained for CARA, but an extra region (region 0) was created for the central Arctic Ocean. In cases where the newly defined provinces were essentially the same as the original provinces (with slightly modified borders), the original province numbers and names were maintained. The total petroleum systems and assessment units were mostly new for the 2008 CARA, rather than revisions of the 2000 assessment units. Identification of scenarios is recorded where used.

\section{Characteristics of Assessment Unit}

The input form uses a classification of assessment units based on level of exploration. One of five categories of exploration level was chosen based on the highest level of exploration achieved. The number of producing fields, discoveries, or wells drilled was recorded.

\section{Geologic Analogs Used in Estimating Geologic Input}

A section was added to the geologic input form to document the use of geologic analogs. Different analogs or analog sets were commonly used for different variables. For example, sizes and numbers of accumulations may have come from a set of analogs chosen to have a similar type of trap or sedimentary environment (for example, a unit could be compared to all analogs with deep-water turbidite traps). The same assessment unit may have used a different analog set to determine the relative oil/gas mix (for example, all analogs with lacustrine source rocks).

\section{Scenario Probability}

In most cases, the uncertainty in input variables was handled by simple, unimodal distributions. In some cases, 
however, different geologic models produced multimodal distributions for numbers or sizes of accumulations that were better captured by more than one scenario, each with an associated probability. The sum of scenario probabilities must equal 1 . The input for each scenario was recorded on a separate input form.

\section{Assessment Unit Probability}

Assessment unit probabilities were disaggregated into three independent probabilities for charge, rocks, and timing. The charge probability includes all factors relating to fluids, such as the existence of source rocks and an appropriate generation and migration history. The rocks probability includes all factors dealing with the reservoir and trap existence and quality. The timing probability pertains to appropriate temporal order of trap existence and fluid migration. Risk associated with petroleum system destruction and preservation is also included under timing.

\section{Numbers of Undiscovered Oil and Gas Accumulations}

Two approaches were taken in generating the distributions for numbers of undiscovered oil and gas accumulations, depending on the data available. In areas with at least moderate exploration, exploration history plots were constructed and trends in exploration observed. In areas with little or no exploration, an analog approach was determined to be more appropriate.

The input for numbers of accumulations are truncated, shifted lognormal distributions and are separate for oil and for gas accumulations. The distributions are each described by a minimum, a median, and a maximum value. The distributions are conditional distributions; they are the distribution given that at least one undiscovered accumulation of minimum size exists. The three parameters (minimum, median, and maximum) need not be integers, but commonly were input as such. The truncated, shifted lognormal distribution allows for greater skewness in the uncertainty distribution than is possible with a triangular distribution.

The minimum number of accumulations can be zero for one, but not both, of the oil and gas number distributions. The assessment unit probability is the probability of existence of at least one undiscovered accumulation of indeterminate type. Thus, for example, the assessment unit risk may apply to the existence of at least one oil accumulation, but a zero minimum number of gas accumulations would further risk the existence of gas accumulations.

Data useful for estimating numbers of undiscovered accumulations included data about numbers of discovered accumulations, prospect information, numbers of fields per $1,000 \mathrm{~km}^{2}$ (from the geologic analog database), and number of oil accumulations divided by number of gas accumulations (from the geologic analog database).
The OilGasPhase program (appendix 1) was developed to help generate distributions for numbers of oil and gas accumulations in cases where the mix of oil and gas accumulations was uncertain. In this approach, which was used most commonly, the distribution for total number of undiscovered accumulations was estimated (commonly from geologic analogs) and a probability distribution for oil/gas mix was also estimated.

\section{Sizes of Oil and Gas Accumulations}

Size distributions of oil and gas accumulations are represented as separate truncated shifted lognormal distributions. The distributions are described by three parameters: the minimum, the median, and the maximum. For the CARA project, the minimum accumulation size used in all assessments was 50 million barrels of oil equivalent.

\section{Coproduct Ratios}

Coproduct ratios were handled in a different way than the methodology for the 2000 World Petroleum Assessment. That earlier form used the distributions of the average of each ratio and the uncertainty about each average. These ratios were applied after the summing of oil volumes in oil accumulations (or gas volumes in gas accumulations) and thus the distribution expressing the uncertainty of the average was appropriate.

For the 2008 CARA, the form required the coproductratio distributions to be that of values for accumulations, as provided from the databases, rather than an assessment unit average. At each iteration of the Monte Carlo program, each simulated accumulation size (oil volumes in oil accumulations or gas volumes in gas accumulations) was multiplied by the appropriate coproduct ratios before the summing of volumes.

The geologic input form describes the coproduct-ratio distributions by three parameters - the minimum, the median, and the maximum. The coproduct ratios are represented as truncated shifted lognormal distributions. Global distributions of each of these ratios are also available as a default (table 1).

\section{Ancillary Data}

Ancillary data distributions are described by fractiles without the specification of any particular distribution form. Global distributions of each of these variables are also available as a default (table 1).

\section{Allocations}

Allocations were made to north and south of the Arctic Circle, to the offshore, to onshore parts of countries, and to provinces. The offshore was not allocated to any country because of indeterminate offshore country boundaries in some areas. Although all assessment units were within single provinces, they were not constrained to be so. 
Table 1. Global default values for coproduct ratios and ancillary data used in the Circum-Arctic Resource Appraisal geologic assessments.

\begin{tabular}{lccc}
\hline \multicolumn{1}{c}{ Variable } & Minimum & Median & Maximum \\
\hline \multicolumn{1}{c}{ Coproduct ratios } & & & \\
\hline $\begin{array}{l}\text { Ratio of natural gas to crude oil in oil accumulations (in cubic feet per barrel) } \\
\text { Ratio of natural gas liquids to natural gas in oil accumulatios (in barrels per }\end{array}$ & 100 & 1,000 & 20,000 \\
$\quad$ thousand cubic feet) & 5 & 25 & 85 \\
$\begin{array}{l}\text { Ratio of natural gas liquids to natural gas in gas accumulations (in barrels per } \\
\quad \text { thousand cubic feet) }\end{array}$ & 5 & 25 & 75 \\
Ancillary data for oil accumulations & & & \\
API gravity (in degrees) & 20 & 38 & 55 \\
Viscosity (in centipoise) & 0.01 & 3 & 30 \\
Sulfur content of oil (in percent) & 0 & 0.3 & 1.5 \\
Ancillary data for gas accumulations & & & 10 \\
Inert gas content (in percent) & 0 & 2 & 10 \\
Carbon dioxide content (in percent) & 0 & 1.5 & 3.5 \\
Hydrogen sulfide content (in percent) & 0 & 0.5 & 2,700 \\
Depths & & & 7,000 \\
Depth (in meters) of water (if applicable) & 0 & 50 & 2,000 \\
Drilling depth (in meters) & 350 & & \\
\hline
\end{tabular}

The area percentages for each allocation component came from GIS (geographic information systems) and were based on the assessment unit boundaries. Point estimates for resource volume percents were requested because the constraint of allocations adding to 100 percent made the use of probabilistic estimates difficult.

\section{Monte Carlo Simulation}

Two Monte Carlo programs were developed for use in the Circum-Arctic Resource Appraisal. Both were modifications of the program used in the 2000 World Petroleum Assessment (Charpentier and Klett, 2000). One program was used for those cases with only one scenario; the other program could handle multiple scenarios. The programs were both Microsoft Excel workbooks requiring Oracle Crystal Ball software to run.

During the assessment meeting, the Monte Carlo program was run with a small number of iterations $(1,000$ to 5,000$)$ to give feedback to the assessment review team, particularly feedback concerning the distribution for largest undiscovered accumulations. If the results of the calculations were considered to correctly reflect the geologic knowledge and uncertainty, the input form was finalized. If not, the input was modified and the program run until the results captured the geologic model appropriately. After the assessment meeting, the program was run for 50,000 iterations to give a stable, official set of estimates.

\section{Aggregation}

For aggregation of the probabilistic results, the assessment team created three matrices of geologic similarities among assessment units for charge, rocks, and timing. The high, medium, low, and background similarities assessed by the geoscientists were given numeric values and the three matrices were averaged. The resulting matrix was slightly modified to assure that it was a valid correlation matrix and then the final matrix was used to aggregate the assessment unit results, or allocated portions thereof (such as the offshore component) into larger units (Schuenemeyer and Gautier, 2010).

\section{References Cited}

Charpentier, R.R., and Klett, T.R., 2000, Monte Carlo simulation method, chapter MC, in U.S. Geological Survey World Petroleum Assessment 2000 - Description and results by U.S. Geological Survey World Energy Assessment Team: U.S. Geological Survey Digital Data Series DDS-60, ver. 1.1, 15 p. [4 CD-ROMs; also available at http://energy. cr.usgs.gov/WEcont/chaps/MC.pdf]

Charpentier, R.R., Klett, T.R., and Attanasi, E.D., 2008, Database for assessment unit-scale analogs (exclusive of the United States): U.S. Geological Survey Open-File Report 2007-1404, 61 p. [Also available at http://pubs.usgs.gov/ of/2007/1404/] 
Grantz, Arthur, Scott, R.A., Drachev, S.S., and Moore, T.E., 2010, Maps showing the sedimentary successions of the Arctic Region $\left(58^{\circ}-64^{\circ}\right.$ to $\left.90^{\circ} \mathrm{N}\right)$ that may be prospective for hydrocarbons, 2d ed.: American Association of Petroleum Geologists, accessed on October 15, 2015, at http:// datapages.com/gis-map-publishing-program/gis-open-files/ geographic/sedimentary-successions-of-the-arctic-regionby-grantz-et-al-2010].

IHS Energy Group, 2007 [includes data current through October 2007], International exploration and production database: Englewood, Colo., IHS Energy Group [database available from IHS Energy Group, 15 Inverness Way East, D205, Englewood, CO 80112, U.S.A.].

Schuenemeyer, J.H., and Gautier, D.L., 2010, Aggregation methodology for the Circum-Arctic Resource Appraisal: Mathematical Geoscience, n. 42, p. 583-594.

U.S. Geological Survey World Energy Assessment Team, 2000, U.S. Geological Survey World Petroleum Assessment 2000-Description and Results: U.S. Geological Survey Digital Data Series 60, ver. 1.1, 15 p. [4 CD-ROMs]. [Also available at http://pubs.usgs.gov/dds/dds-060/.] 


\section{Appendixes}

Appendixes are available online only, and may be accessed at https://doi.org/10.3133/pp1824B

Appendix 1. Monte Carlo Program for Estimating Oil/Gas Accumation Mix

Appendix 2. Basin Evolution Chart

Appendix 3. Circum-Arctic Resource Appraisal Geologic Data Form for Conventional Assessment Units 


\section{曾}

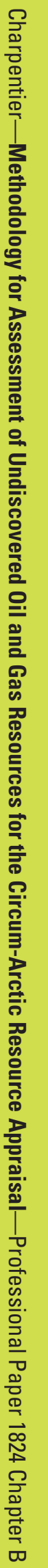

